\title{
High chimpanzee and gorilla densities in a non-protected area on the northern periphery of the Dja Faunal Reserve, Cameroon
}

\author{
J. Dupain, P. Guislain, G. M. Nguenang, K. De Vleeschouwer and L. Van Elsacker
}

\begin{abstract}
Information on the densities of threatened species in non-protected areas is crucial for assessing the degree of isolation of adjacent protected areas and consequently their potential for preserving species from extinction. Relatively few studies, however, provide such information. We present the results of a survey of the densities of two great ape species, the gorilla Gorilla gorilla gorilla and chimpanzee Pan troglodytes troglodytes, in a non-protected area on the northern periphery of Dja Faunal Reserve, Cameroon. Densities of chimpanzees and gorillas were estimated to be 1.1 and 3.8 weaned individuals per $\mathrm{km}^{2}$, respectively. The results confirm that gorillas prefer building nests in vegetation types with limited visibility, and that within preferred vegetation types for nesting, gorillas select patches that are the most difficult to penetrate, resulting in less conspicuous
\end{abstract}

nests. Although the opposite tendencies were exhibited by chimpanzees, no firm conclusions could be drawn from our data. Despite its non-protected status and past and ongoing logging activities in the area, the densities of gorillas and chimpanzees on the northern periphery of Dja Faunal Reserve are comparable to those found within the reserve itself, indicating the need for developing alternative conservation action to protect these important populations. The creation of a Communal Wildlife Zone in this area is legislatively possible, and could be an effective conservation tool because it has to originate from the local people.

Keywords Cameroon, chimpanzee, Dja Faunal Reserve, Gorilla gorilla gorilla, nesting behaviour, nonprotected area, Pan troglodytes troglodytes.

\section{Introduction}

Southern Cameroon is covered by c. $200,000 \mathrm{~km}^{2}$ of dense forest (Hutter, 2000), most of which is potential habitat for gorillas Gorilla gorilla gorilla and chimpanzees Pan troglodytes troglodytes (Dupain, 2001). Following the Yaoundé Declaration in 1999 c. 10\% of this habitat will be granted a protected status (Centre pour l'Environnement et le Developpement, 1999). Past great ape surveys have mainly focussed on these protected areas (Williamson \& Usongo, 1995; Ekobo, 1998; Usongo, 1998; van der Wal \& Nku, 1999). Effective protected area management, however, requires information on, and conservation activities in, the surrounding matrix (Tutin, 2003). If not, protected areas become islands threatened by increasing human pressure (Dupain, 2001).

J. Dupain (Corresponding author), ${ }^{\star} \mathrm{K}$. De Vleeschouwer and *L. Van Elsacker Centre for Research and Conservation, Royal Zoological Society of Antwerp, Koningin Astridplein 26, 2018 Antwerp, Belgium. E-mail jef.dupain@ zooantwerpen.be

P. Guislain Strijdersstraat 65, 3000 Leuven, Belgium.

G. M. Nguenang Université de Yaoundé 1, Yaoundé, Cameroon

*Also at: Department of Biology, University of Antwerp, Universiteitsplein 1, 2610 Antwerp, Belgium.

Received 5 September 2002. Revision requested 4 March 2003 Accepted 24 November 2003.
The $5,260 \mathrm{~km}^{2}$ Dja Faunal Reserve is the largest protected area in Cameroon in which intensive surveys and continuous monitoring of large mammals are being conducted. The reserve harbours important populations of large mammals, including chimpanzees and gorillas (Nzooh-Dongmo, 2001; Dupain et al., 2003) but it is becoming more isolated as a result of increasing human population densities (Moamosse, 1990; Fomete Nembot \& Tchanou, 1998) and intense logging activities (Fomete Nembot \& Tchanou, 1998; Hutter, 2000) on its periphery. In addition, hunting pressures in the area around the Reserve are reported to be relatively high (Muchaal \& Ngandjui, 1999). However, the fact that gorillas and chimpanzees are still being hunted on the periphery of the reserve (Prescott et al., 1993-1994; van der Wal \& $\mathrm{Nku}, 1999$ ) indicates that populations of both species are surviving in the non-protected surrounding area. NzoohDongmo (2001) has stressed the need for more surveys and research on this periphery, in addition to studies within the Reserve. Such studies are necessary to assess the potential of the Reserve for long-term species preservation, and to formulate a comprehensive regional conservation strategy.

In this paper we present the results of the first survey of the presence and densities of chimpanzees and gorillas in a forest block in the northern periphery of the Dja Faunal Reserve. The survey was conducted in a Communal Forest, which is reserved to be managed 
by the municipality (Art.3 (12) of the decree 94/436/PM of August 23, 1994). Potentially this forest can become a Communal Wildlife Zone, i.e. an area in which sustainable management of the fauna is being accomplished by the local population (Art.3 (1) of the decree 95/466/ PM of July 20, 1995). We conducted this survey in order to assess the potential of this non-protected area for great ape conservation. Given that the study area is located between two sites used by a logging company, the fact that it was opened by logging roads c. 15 years ago, and considering the hunting pressure caused by people living in a populated area to the north of the study area, we expected to find low densities of both great ape species.

We further expected the distribution of chimpanzee and gorilla nests among the different vegetation types to be divergent, with chimpanzees preferring primary forest (Tutin \& Fernandez, 1984) and gorillas preferring herbaceous vegetation (Tutin et al., 1995; Williamson \& Usongo, 1995; Usongo, 1998 ). Non-random nest site selection by gorillas has been related to an attraction to their preferred herbaceous food types (Tutin et al., 1995). Alternatively, it has been suggested that gorillas select nest sites in denser vegetation, where nests are less conspicuous, in reaction to high hunting pressure from humans (Blake, 1993; Lahm, 1993). If hunting pressure explains gorilla nest site preference, we expect nest sites to be within patches that have the densest undergrowth, i.e. patches with the lowest visibility.

\section{Material and Methods}

\section{Study area}

The survey was conducted in a $30 \mathrm{~km}^{2}$ forest block known as Ntonga, on the northern periphery of the Dja Faunal Reserve, Cameroon (Fig. 1). Ntonga is situated in the transition zone of the Atlantic coastal rainforests of southern Nigeria and south-west Cameroon, and the evergreen forests of Equatorial Guinea and the Congo Basin (Letouzey, 1985). Annual rainfall averages $1,570 \mathrm{~mm}$ and most precipitation falls during two wet seasons, March-June and September-November. The main dry season is between December and FebruaryMarch. Temperature remains almost constant throughout the year, and averages $23^{\circ} \mathrm{C}$ (Protected Areas Programme, 2001). In the south, the study area is bordered by the private road of the logging company $\mathrm{R}$. Pallisco, in the west and the north by the river Mpouo and in the east by a high altitude crest. Traditionally the

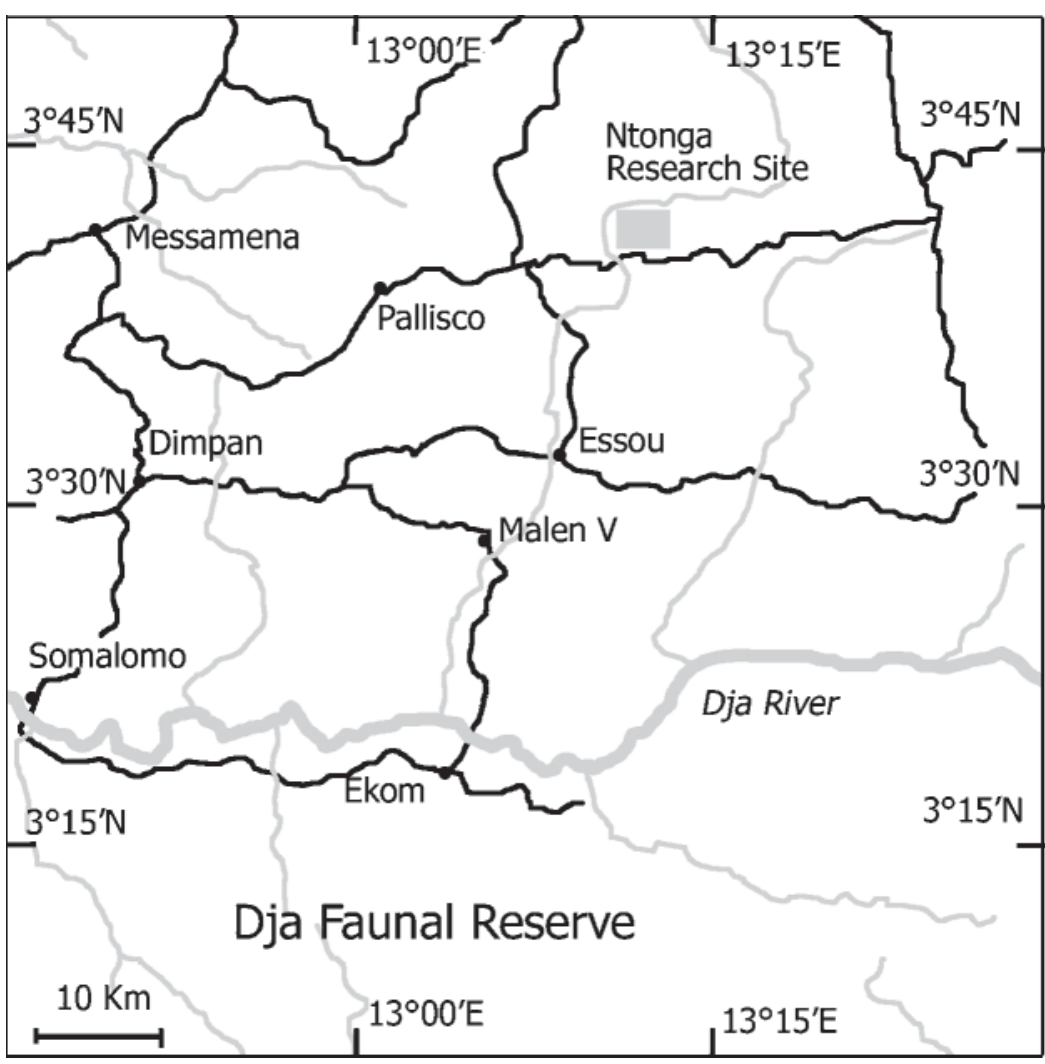

Fig. 1 The location of the study area of Ntonga on the northern periphery of the Dja Faunal Reserve in Cameroon. 
forest belongs to the village of Mboumo (400 inhabitants), $20 \mathrm{~km}$ west of Ntonga. Communities of Baka pygmies inhabit the area and its surroundings. The area attracts hunters from both Mboumo and more northerly regions (10-30 km from the study site). The c. 1,000 km² area between Ntonga and the Reserve is Forest Management Unit 10047.

\section{Classification of vegetation and measurement of horizontal visibility}

A total of 12 parallel transects were cut, with distances between transects of $500 \mathrm{~m}$. The transects were oriented in a north-south direction and located between the logging road and the river Mpouo. Transects were 3-5.5 km long, and totalled $57.7 \mathrm{~km}$. They were marked with plastic labels at $50 \mathrm{~m}$ intervals. At each interval the vegetation type and horizontal visibility were recorded. Horizontal visibility is defined as the distance at eye level $(1.7 \mathrm{~m})$ beyond which objects can no longer be seen. In order to avoid inter-observer variability, visibility was estimated by JD in all cases.

Seven types of vegetation were distinguished: PF, primary forest with large trees such as Piptadeniastrum africanum and an open undergrowth; OSF, old secondary forest with little undergrowth; SF, secondary forest with a discontinuous canopy layer and more pronounced patches of Marantaceae (Haumania danckelmania and Megaphrynium macrostachyum) than old secondary forest; YSF, young secondary forest with a relatively dense undergrowth of Marantaceae and Zingiberaceae and a canopy height of $<15 \mathrm{~m}$; SW, swamp forest characterized by a high density of Raphia mobutterum, numerous species of Marantaceae and Zingiberaceae such as Halopegea azura, Marantochloa purpurea and Costus spp.; RF, riverine forest, periodically inundated, with a mixture of species of both swamp and terra firma forests; LRF, old logging road forest with a high density of Marantaceae and Zingiberaceae and characterized by Macaranga spp. and Calancoba spp.

\section{Estimation of chimpanzee and gorilla densities}

Densities of chimpanzee and gorilla nest sites were estimated using the standing crop nest count method (Plumptre \& Reynolds, 1996). Over a 4-week period in February-March 2000 all transects were walked once at a speed of approximatively $1 \mathrm{~km} \mathrm{~h}^{-1}$. When a nest was encountered, other nests belonging to the same nest group were located. Nests from the same species located within $20 \mathrm{~m}$ of each other and of similar age category were considered to belong to the same nest group. For each nest, we scored five parameters: (1) Age category, divided into five classes (all nest leaves green and fresh faeces/urine under, in or next to nest; all leaves green, no fresh urine/faeces; nest of brown/dried and green leaves; leaves completely brown but nest still complete; nest decomposing), (2) location along the transect line, (3) perpendicular distance from the nest to the transect, (4) vegetation type, and (5) estimated visibility at eye level $(1.7 \mathrm{~m})$.

We did not encounter any nest groups with both tree nests and ground nests. All nest groups were checked for any evidence that could distinguish between gorillas and chimpanzees (traces and faeces). Although all long-term studies confirm that gorillas build tree nests, we found no evidence for tree nests belonging to gorillas or ground nests belonging to chimpanzees. Thus, we considered all nest groups on the ground to be constructed by gorillas and all those in trees to be constructed by chimpanzees. However, as the decay rate of tree nests is lower than that of ground nests, older sites with tree nests only may potentially be misinterpreted as chimpanzee nest sites. As surveys in the Dja Faunal Reserve report that 3.4\% of gorilla nests are built in trees (Williamson \& Usongo, 1995) and as we conducted the survey during the main dry season, whereas gorilla tree nest building is positively correlated with rainfall (Tutin et al., 1995), we assume that misidentifications were limited.

For each nest group we calculated its geographical centre. Nest site density was estimated using distance sampling, calculated with the computer software Distance 3.5 (Thomas et al., 1998). As the probability of sighting nests falls off with distance from the transect, Distance 3.5 uses a detection curve to estimate density. We used the Akaike Information Criterion (Buckland et al., 1993) to select the best model for analysis of the perpendicular distances from nest sites to the centre line of a transect. For chimpanzee nest sites we selected the half normal model, and for gorilla nest sites the hazard rate model. For transformation of nest site density to densities of nest building (i.e. weaned) individuals, we used mean nest group size and a fixed parameter for the nest decay rate. We used 113.5 days as the mean life span of chimpanzee nests (Tutin \& Fernandez, 1984) and 78 days as the mean life span of gorilla nests (Tutin et al., 1995). The use of nest decay rates from other studies in a different setting is open to criticism because nest decay rate depends on the nest material used, seasonality and climatic conditions. The variance of this decay rate is unknown. As a consequence, the estimates of great ape densities do not include any confidence limits and should therefore be interpreted cautiously.

\section{Statistical analyses}

We used exact $\chi^{2}$ goodness-of-fit-tests to determine whether chimpanzee and gorilla nest sites were randomly distributed amongst the different vegetation types. Expected values were calculated as $\operatorname{Exp}_{\mathrm{a}}=\left(x_{\mathrm{i}}^{*} y_{\mathrm{a}} / 100\right)$, 
Table 1 Percentage of occurrence of seven vegetation types* in the study area, their average horizontal visibility at eye level, the number of chimpanzee and gorilla nest groups in each vegetation type, and horizontal visibility at eye level at nest sites.

\begin{tabular}{|c|c|c|c|c|c|c|c|}
\hline & PF & OSF & SF & YSF & SW & RF & LRF \\
\hline Proportion of study area (\%) & 17.6 & 10.8 & 39.3 & 15.6 & 9.3 & 5.3 & 2.1 \\
\hline Average visibility $\pm S D(m)$ & $\begin{array}{l}13.6 \pm 8.1 \\
(n=172)\end{array}$ & $\begin{array}{l}11.0 \pm 5.8 \\
(n=92)\end{array}$ & $\begin{array}{l}8.8 \pm 6.6 \\
(n=381)\end{array}$ & $\begin{array}{l}5,6 \pm 4.5 \\
(n=153)\end{array}$ & $\begin{array}{l}9.4 \pm 6.2 \\
(n=83)\end{array}$ & $\begin{array}{l}10.1 \pm 6.2 \\
(n=46)\end{array}$ & $\begin{array}{l}5.4 \pm 4.9 \\
(n=22)\end{array}$ \\
\hline \multicolumn{8}{|l|}{ Chimpanzees } \\
\hline Number of nest groups $(n=91)$ & $25(27.4 \%)$ & $20(22.0 \%)$ & $31(34.1 \%)$ & $11(12.1 \%)$ & $2(2.2 \%)$ & $2(2.2 \%)$ & $0(0.0 \%)$ \\
\hline $\begin{array}{l}\text { Av. visibility at nest group site } \pm S D(m) \\
\text { within } 12 \mathrm{~m} \text { strip } \\
\text { Gorillas }\end{array}$ & $\begin{array}{l}15.4 \pm 4.6 \\
(n=5)\end{array}$ & $\begin{array}{l}11.4 \pm 6.1 \\
(n=5)\end{array}$ & $\begin{array}{l}15.2 \pm 6.2 \\
(n=12)\end{array}$ & $\begin{array}{l}6.5 \pm 0.7 \\
(n=2)\end{array}$ & & $\begin{array}{l}6.0 \\
(n=1)\end{array}$ & \\
\hline Number of nest groups $(n=66)$ & $4(6.1 \%)$ & $2(3.0 \%)$ & $16(24.2 \%)$ & $17(25.8 \%)$ & $15(22.7 \%)$ & $1(1.5 \%)$ & $11(16.7 \%)$ \\
\hline $\begin{array}{l}\text { Av. visibility at nest group site } \pm S D(m) \\
\text { within } 12 \mathrm{~m} \text { strip }\end{array}$ & $\begin{array}{l}2.0 \pm 0.0 \\
(\mathrm{n}=2)\end{array}$ & & $\begin{array}{l}1.9 \pm 3.2 \\
(\mathrm{n}=7)\end{array}$ & $\begin{array}{l}1.9 \pm 1.9 \\
(\mathrm{n}=11)\end{array}$ & $\begin{array}{l}5.8 \pm 5.5 \\
(\mathrm{n}=5)\end{array}$ & $\begin{array}{l}0.0 \\
(\mathrm{n}=1)\end{array}$ & $\begin{array}{l}2.3 \pm 2.2 \\
(\mathrm{n}=6)\end{array}$ \\
\hline
\end{tabular}

${ }^{*} \mathrm{PF}$, primary forest; OSF, old secondary forest; SF, secondary forest; YSF, young secondary forest; SW, swamp forest; RF, riverine forest; LRF, old logging road forest (see text for further details).

where $x$ is the percentage of vegetation type i within the study area, and $y$ is the total number of nest groups of species $a$. A preference index was calculated as the difference between the number of nest sites expected if they were randomly distributed and the observed number of nest sites within a specific vegetation type.

Differences in visibility between vegetation types were tested with ANOVA and Scheffé post-hoc tests. The same technique was used to determine differences in visibility between nest sites and the average visibility scores of all vegetation types. In order to avoid bias towards sites in patches of higher visibility, we only included data for nest sites within $6 \mathrm{~m}$ of the transect (a $12 \mathrm{~m}$ strip), i.e. the distance at which the detection curve (see above) falls off. Finally, we analysed whether gorillas and chimpanzees select patches with lower/higher visibility within each specific vegetation type. As the data was insufficient for a parametric ANOVA, Kruskal-Wallis one way ANOVA by ranks (Siegel \& Castellan, 1988) was used. Comparisons were only made where $n>5$.

\section{Results}

A total of 247 chimpanzee nests in 94 nest groups and 288 gorilla nests in 69 nest groups were recorded.
Chimpanzee and gorilla nest site densities were $49.9 \mathrm{~km}^{-2}$ (range 28.2-88.1; coefficient of variation $26.8 \%$ ) and $78.4 \mathrm{~km}^{-2}$ (range 54.4-113.0; coefficient of variation $22.8 \%$ ) respectively. This gives density estimates of 1.1 and 3.8 weaned chimpanzees and gorillas per $\mathrm{km}^{2}$, respectively.

The majority of the study area $(65.7 \%)$ is characterized by secondary forest (Table 1), $24 \%$ of which has relatively dense undergrowth (i.e. young secondary forest). Horizontal visibility differed significantly between vegetation types $\left(F_{6,948}=22.88, \mathrm{P}<0.01\right)$. Visibility in old logging road forest and young secondary forest is limited (5-6 m), while primary, old secondary and riverine forest are characterized by higher levels of visibility (10-14 m). Visibility in old logging road forest differs significantly from all vegetation types except young secondary forest and secondary forest, and visibility in primary forest differs significantly from all vegetation types except riverine forest and old secondary forest (Table 2).

Within a $12 \mathrm{~m}$ strip, details of the vegetation types where nest groups occurred were available for 25 chimpanzee and 32 gorilla nest groups. The distribution of chimpanzee nest groups did not differ from random (Table $1 ; \chi^{2}=6.38, \mathrm{P}=0.38$ ), whereas that of gorilla nest

Table 2 Post-hoc analysis (Scheffé), with standard deviations in parentheses, for differences in visibility between the seven vegetation types. Abbreviations as Table 1.

\begin{tabular}{|c|c|c|c|c|c|c|c|}
\hline & PF & OSF & SF & YSF & LRF & SW & RF \\
\hline $\mathrm{PF}$ & & $2.46(0.83)$ & $4.62^{* *}(0.59)$ & $7.81^{* *}(0.71)$ & $8.04^{* *}(1.46)$ & $4.04^{* *}(0.86)$ & $3.36(1.07)$ \\
\hline OSF & & & $2.16(0.75)$ & $5.36^{* *}(0.85)$ & $5.58^{*}(1.53)$ & $1.58(0.98)$ & $0.90(1.17)$ \\
\hline SF & & & & $3.20^{* *}(0.62)$ & $3.42(1.42)$ & $-0.58(0.78)$ & $-1.26(1.01)$ \\
\hline YSF & & & & & $0.22(1.47)$ & $-3.78^{* *}(0.88)$ & $-4.46^{* *}(1.09)$ \\
\hline LRF & & & & & & $-4.00(1.55)$ & $-4.68(1.67)$ \\
\hline SW & & & & & & & $-0.68(1.19)$ \\
\hline $\mathrm{RF}$ & & & & & & & \\
\hline
\end{tabular}

${ }^{*} \mathrm{P}<0.05,{ }^{* *} \mathrm{P}<0.01$ 


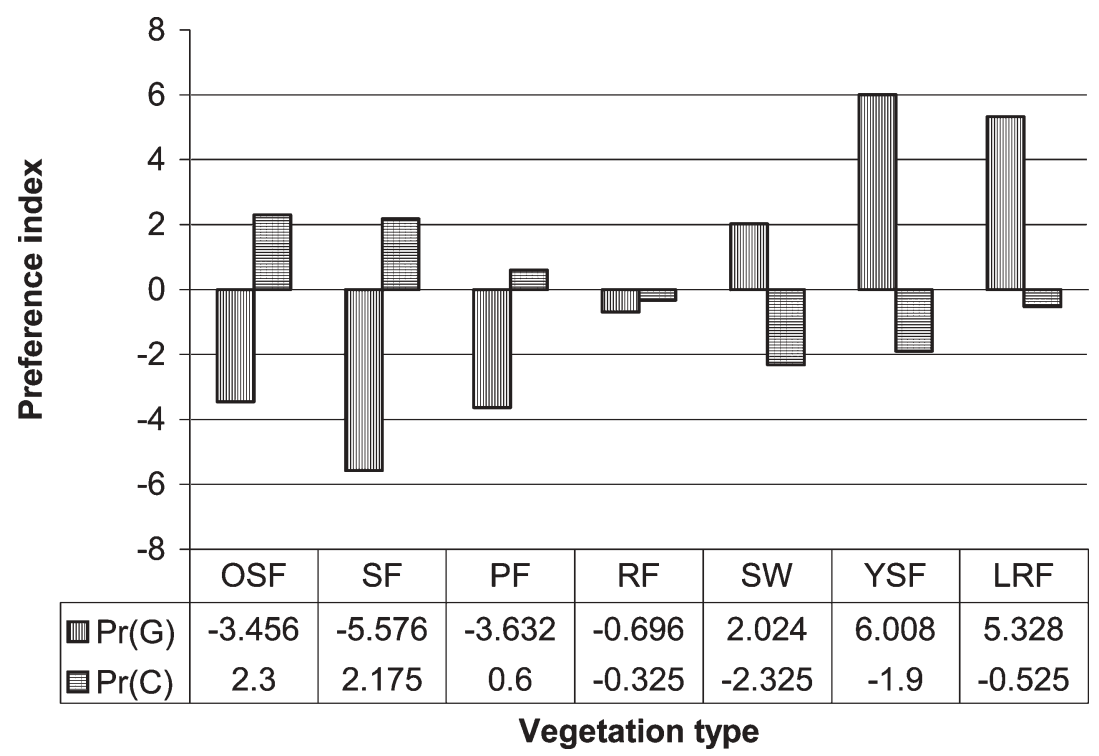

Fig. 2 Preferences, calculated as an index (see text for further details), of gorillas $(\operatorname{Pr}(\mathrm{G}))$ and chimpanzees $(\operatorname{Pr}(\mathrm{C}))$ for siting their nests in specific vegetation types: OSF, old secondary forest; SF, secondary forest; $\mathrm{PF}$, primary forest; $\mathrm{RF}$, riverine forest; SW, swamp forest; YSF, young secondary forest; LRF, old logging road forest (see text for further details). groups did (Table $1 ; \chi^{2}=59.41, \mathrm{P}<0.01$ ). When considered as a preference index (observed value - expected value), visual inspection indicates that chimpanzees tended to prefer old secondary, secondary and primary forests for nest building, whereas gorillas preferred young secondary, old logging road and swamp forests (Fig. 2).

Visibility at gorilla nest sites, at chimpanzee nest sites and the average visibility differ significantly $\left(F_{2,1005}=20.58 ; \mathrm{P}<0.01\right)$. Scheffé post-hoc analysis indicated that visibility at chimpanzee and gorilla nest sites is significantly higher and lower, respectively, than average.

Within vegetation types, gorillas preferred nesting in patches where horizontal visibility was less than average. Results were statistically significant for secondary (Kruskal-Wallis ANOVA $=10.91 ; \mathrm{P}<0.01$ ) and young secondary (Kruskal-Wallis ANOVA $=9.88, \mathrm{P}<0.01$ ) forests. Although not statistically significant, the same tendency was observed in all other vegetation types. Chimpanzees tended to nest in patches where horizontal visibility is slightly higher than average within that vegetation type, although a significant difference was only observed for secondary forest (Kruskal-Wallis ANOVA $=11.82, \mathrm{P}<0.01)$.

\section{Discussion}

This survey indicates that important populations of chimpanzees and gorillas still survive in the northern periphery of the Dja Faunal Reserve, despite its non-protected status, indicating the importance of such non-protected areas as buffer zones for adjacent reserves.
Table 3 Densities (individuals per $\mathrm{km}^{2}$, with range) of chimpanzees and gorillas in this survey at Ntonga, compared with four other surveys in Cameroon.

\begin{tabular}{|c|c|c|c|}
\hline Location & Chimpanzees & Gorillas & Reference \\
\hline Ntonga & 1.09 & 3.87 & This study \\
\hline $\begin{array}{l}\text { Dja Faunal } \\
\text { Reserve }\end{array}$ & $0.79(0.6-1.04)$ & $1.70(1.02-2.86)$ & $\begin{array}{l}\text { Williamson \& } \\
\text { Usongo (1995) }\end{array}$ \\
\hline $\begin{array}{l}\text { Dja Faunal } \\
\text { Reserve }\end{array}$ & $0.7(0.6-0.9)$ & $1.9(1.3-2.7)$ & $\begin{array}{l}\text { Van der Wal } \\
\quad \& \text { Nku (1999) }\end{array}$ \\
\hline Lac Lobeke & 0.14 & $1.6(0.2-6.4)$ & WCS (1996) \\
\hline $\begin{array}{l}\text { Boumba-Bek/ } \\
\text { Nki }\end{array}$ & $0.02-0.3$ & $0.6-3.0$ & Ekobo (1998) \\
\hline
\end{tabular}

In addition, the densities of both gorillas and chimpanzees in Ntonga forest are amongst the highest reported so far in Cameroon (Table 3). These non-protected populations will need to be considered in any discussion of the Cameroonian National Action Plan for the Survival of Great Apes (Great Ape Survival Plan, 2003).

Using nest count methods to estimate great ape density has some limitations (Plumptre \& Reynolds, 1996). The rate of nest decay used can have a large impact on the accuracy of the estimate (Remis, 2000). The decay rate is known to vary considerably between distant study areas. In this study, however, we wished to understand the importance of the surveyed area compared to nearby protected areas, and to allow comparisons to be made (Table 3) we therefore used the same methodology and parameters as used at other sites in Cameroon (Williamson \& Usongo, 1995; Ekobo, 1998; van der Wal \& Nku, 1999). Additionally, distance sampling analysis corrects for different detection functions at different 
sites, and thus decreases potential bias. However, nest decay rates may also differ seasonally. Wrogeman (1992) reports prolonged longevity of gorilla nests during the dry season, and because we conducted our survey at the end of the dry season we might therefore have overestimated the density of gorilla nests. Chimpanzee nests, however, seem to decompose faster during the dry season (Plumptre \& Reynolds, 1996) and their density might thus have been underestimated.

The findings of our survey were contrary to our expectations: densities of both gorillas and chimpanzees were comparable to those in the Dja Faunal Reserve, rather than lower. The study area was first logged c. 15 years ago (V. Pelé, pers.comm.), and the effect of logging on the bushmeat trade is well documented (World Society For The Protection of Animals, 1995). Logging roads open up the forest for hunters, logging sites become important bushmeat markets, and logging trucks and boats facilitate the transport of bushmeat into urban markets and the transport of guns and cartridges into the forest (Ape Alliance, 1998; Butinsky, 2000; World Society For The Protection of Animals, 2000; Dupain \& Van Elsacker, 2001a, 2001b). The estimated densities of both gorillas and chimpanzees in the Ntonga forest are therefore unexpectedly high. This contrasts with the results of surveys conducted in the eastern periphery of the Reserve, where encounter rates per $\mathrm{km}$ for gorilla and chimpanzee traces are 3 and 30 times lower, respectively, than within the Reserve (van der Wal \& Nku, 1999).

One explanation for the discrepancy between this latter survey and that in Ntonga may be that Ntonga is far $(>15 \mathrm{~km})$ from the nearest villages. Although we found ample evidence of hunting (hunting camps, snares and cartridges), informal discussions with the local community indicated the low level of specialized great ape hunting. We assume that great ape and elephant hunting is mostly limited to the activity of a few specialized hunters, and it appears that these have not yet focused on the study area. In the absence of increased hunting for great apes, logging may influence great ape densities through changes in vegetation. Forest regeneration after logging results in vegetation with denser undergrowth. Accordingly an increased number of gorilla nest sites can be expected in logged forests (Usongo, 1998), whereas chimpanzee densities are expected to decrease (Tutin \& Fernandez, 1984; Skorupa, 1988; Usongo, 1998). The particularly high encounter rates of nest sites in Ntonga might be partly because of relatively high hunting pressure in the forest surrounding Ntonga, which is situated closer to villages. However, more detailed information on densities of great apes in the surrounding forest, and the distribution of hunting and other anthropogenic activities, is needed before any firm conclusions can be drawn.
The preference of gorillas for constructing nests in dense herbaceous vegetation can be explained by the importance of this vegetation type in their diet (Tutin et al., 1995) and/or in terms of avoidance of human activity (Blake, 1993; Lahm, 1993). The vegetation types preferred by gorillas are characterized by dense undergrowth and low visibility (Blom et al., 2001), and consequently low accessibility by humans. If hunting pressure explains their preference we would expect selection of the densest patches within dense vegetation, and this is confirmed by our results. For chimpanzees, the contrary was expected. They are known to prefer forest with little undergrowth and good visibility (Blom et al., 2001), potentially because they sleep in tree nests from which vegetation with open undergrowth will give the optimal view of the approach of potential ground predators and hunters. Although our survey confirmed that chimpanzees construct nests in areas with a higher than average horizontal visibility, a preference for specific vegetation types (Fig. 2) or for more open patches cannot yet be conclusively ascertained.

Given the relatively high densities of both great ape species detected in this study, Ntonga is a potentially important conservation area. Under the land use planning system of Cameroon, the study area belongs to a Communal Forest. This is the result of the Cameroonian forest law of 1994 (Law n94/01 of 20 January 1994). Communal Forest can be declared a Communal Wildlife Zone (Dupain, 2001), but the creation of such a Zone has to be solicited by the local communities in collaboration with the municipality. The communities would be responsible for setting up a sustainable management system for the fauna within the Zone. With its relatively high densities of great apes, the Ntonga forest would be a suitable site for the integration of a fully protected research area for long-term great ape studies into the management plan of such a Communal Wildlife Zone. The research activities would create revenue for the local communities, the research site would become a reservoir of potential prey species from which the surrounding hunting zones could be repopulated, and this reservoir would receive full protection from the local communities. However, the success of Communal Wildlife Zones and similar management systems is not guaranteed (Oates, 1999; Scholte, 2003), and there is a need for the inclusion of scientific research to facilitate the continuous adaptation of such approaches to conservation (Bennett et al., 2002; Rowcliffe, 2002; Sarmiento, 2003). This requires, however, long term institutional and financial support (Plumptre, 2003), the lack of which undermines the credibility of many important conservation initiatives. 


\section{Acknowledgements}

We thank the Wildlife Conservation Society, the European Association of Zoos and Aquaria, the Leopold lll-foundation for Research and Conservation and the Kredietbank for funding this project, the logging company R. Pallisco for their hospitality and the NGO Nature+ (Prof. W. Delvingt, University of Gembloux, Belgium) for suggesting the study area. The research permits were kindly provided by the Ministry for Research and Technology. We are also grateful to the Flemish Government for structural support to the Centre for Research and Conservation (Royal Zoological Society of Antwerp). We thank Tammie MacFie, Isra Deblauwe, Geraldine Clarebout, Catherine Roden, Val and Don Sibley and Jeroen Stevens for their valuable comments on this manuscript. Data collection would have been impossible without the effective help of the Badjoué and Baka trackers of the village of Mboumo, and Wim Jacobs. JD was generously supported by the Center of Excellence Research as a visiting research scholar at the Primate Research Institute (Kyoto University) during the writing of this paper.

\section{References}

Ape Alliance (1998) The African Bushmeat Trade - A Recipe for Extinction. Ape Alliance, London, UK.

Bennett, E.L., Milner-Gulland, E.J., Bakarr, M., Eves, H.E., Robinson, J.G. \& Wilkie, D.S. (2002) Hunting the world's wildlife to extinction. Oryx, 36, 328-329.

Blake, S. (1993) A reconnaissance survey in the Likouala swamps of nothern Congo and its implications for conservation. MSc thesis, University of Edinburgh, Edinburgh, UK.

Blom, A., Almasi, A., Heitkönig, I.M.A., Kpanou, J.-B. \& Prins, H.H.T. (2001) A survey of the apes in the Dzanga-Ndoki National Park, Central African Republic: a comparison between the census and survey methods of estimating gorilla (Gorilla gorilla gorilla) and chimpanzee (Pan troglodytes) nest group density. African Journal of Ecology, 39, 98-105.

Buckland, S.T., Anderson, D.R., Burnham, K.P. \& Laake, J.L. (1993) Distance Sampling: Estimating Abundance of Biological Populations. Chapman \& Hall, London, UK.

Butynski, T.M. (2000) Africa's great apes. Africa: Environment and Wildlife, 8, 33-43.

Centre pour l'Environnement et le Développement (1999) Etat des Lieux du Secteur Forestier au Cameroun-Données Statistiques. Centre pour l'Environnement et le Développement, Yaoundé, Cameroon.

Dupain, J. (2001) Conservation of great apes on the periphery of the Dja Reserve. Gorilla Journal, 23, 18-20.

Dupain, J. \& Van Elsacker, L. (2001a) The status of the bonobo (Pan paniscus) in the Democratic Republic of Congo. In All Apes Great and Small (eds B.M.F. Galdikas, N.E. Briggs, L.K. Sheeran, G.L. Shapiro \& J. Goodall), pp. 57-74. Kluwer Academic/Plenum Publishers, New York, USA.

Dupain, J. \& Van Elsacker, L. (2001b) Status of the proposed Lomako Forest Bonobo Reserve: a case study of the bushmeat trade. In All Apes Great and Small (eds B.M.F.
Galdikas, N.E. Briggs, L.K. Sheeran, G.L. Shapiro \& J. Goodall), pp. 259-273. Kluwer Academic/Plenum Publishers, New York, USA.

Dupain, J., Bombome, K. \& Van Elsacker, L. (2003) Les chimpanzés et les gorilles de la Réserve de Faune du Dja. Canopée, 24, 14-15.

Ekobo, A. (1998). Large Mammals and Vegetation Surveys in the Boumba-bek and Nki Project Area. WWF-CPO, Yaoundé, Cameroon.

Fomete Nembot, T. \& Tchanou, Z. (1998) La gestion des ecosystèmes forestiers du Cameroon de l'aube de l'an 2000. Volume 2. IUCN, Yaoundé, Cameroon.

Great Ape Survival Plan (2003) Cameroon Action Plan for the Survival of Great Apes and Endangered Primates.

Workshop Report, Mfou, Cameroon.

Hutter, C. (ed.) (2000) An Overview of Logging in Cameroon. World Resources Institute, Washington, DC, USA.

Lahm, S.A. (1993) Ecology and economics of human/wildlife interaction in northeastern Gabon. PhD thesis,

New York University, New York, USA.

Letouzey, R. (1985) Notice de la carte phytogéographique du Cameroun au 1:500000. Ed. I. Institut de la carte internationale de la vegetation, Toulouse, France.

Moamosse, D. (1990) Status de la population des gorilles dans la partie nord-ouest de la réserve du Dja. Ecole de Faune, Garoua, Cameroon.

Muchaal, P.K. \& Ngandjui, G. (1999) Impact of village hunting on wildlife populations in the western Dja Reserve, Cameroon. Conservation Biology, 13, 385-396.

Nzooh-Dongmo , Z.-L. (2001) Dynamique de la faune sauvage et des activités anthropiques dans la Réserve de Biosphère du Dja et ses environs. Volume 2. Ministère de 1'Environnement et des Forêts, Réserve de Faune du Dja - ECOFAC-Composante Cameroon, Yaoundé, Cameroon.

Oates, J.F. (1999) Myth and Reality in the Rain Forest. How Conservation Strategies Are Failing in West Africa. University of California Press, Berkeley, USA.

Plumptre, A.J. (2003) The current status of gorillas and threats to their existence at the beginning of a new millennium. In Gorilla Biology: A Multidisciplinary Perspective (eds A.B. Taylor \& M.L.Goldsmith ), pp. 414-431. Cambridge University Press, Cambridge, UK.

Plumptre, A.J. \& Reynolds, V. (1996) Censusing chimpanzees in the Budongo Forest, Uganda. International Journal of Primatology, 17, 85-99.

Prescott, J., Rapley, W.A. \& Mengang, M.J. (1993-1994) Status and conservation of chimpanzee and gorilla in Cameroon. Primate Conservation, 14-15, 7-12.

Protected Areas Program (2001) World Heritage Sites, Cameroon, Dja Faunal Reserve. Http://www.wcmc.org.uk/ protected_areas/data/wh/dja.html [accessed 8 February 2003].

Remis, M.J. (2000) Preliminary assessment of the impact of human activities on gorillas Gorilla gorilla gorilla and other wildlife at Dzanga-Sangha Reserve, Central African Republic. Oryx, 34, 56-65.

Rowcliffe, M. (2002) Bushmeat and the biology of conservation. Oryx, 36, 331.

Sarmiento, E. (2003) Distribution, taxonomy, genetics, ecology, and causal links of gorilla survival: the need to develop practical knowledge for gorilla conservation. In Gorilla Biology: A Multidisciplinary Perspective (eds A.B. Taylor \& M.L. Goldsmith), pp. 432-471. Cambridge University Press, Cambridge, UK. 
Scholte, P. (2003) Immigration: a potential time bomb under the integration of conservation and development. Ambio, 32, 58-64.

Siegel, S. \& Castellan, N.J. (1988) Nonparametric Statistics for the Behavioral Sciences (2nd ed.). McGraw-Hill Book Co., New York, USA.

Skorupa, J.P. (1988) The effects of selective timber harvesting on rainforest primates in Kibale Forest, Uganda. PhD thesis, University of California, Berkeley, USA.

Thomas, L., Laake, J.L., Derry, J.F., Buckland, S.T., Borcheres, D.L., Anderson, D.R., Burnham, K.P., Strindberg, S., Hedley, S.L., Burt, M.L., Margues, F., Pollard, J.H. \& Fewster, R.M. (1998) Distance 3.5. Research Unit for Wildlife Population Assessment. University of St. Andrews, St. Andrews, UK.

Tutin, C.E.G. (2003) An introductory perspective: behavioural ecology of gorillas. In Gorilla Biology: A Multidisciplinary Perspective (eds A.B. Taylor \& M.L. Goldsmith), pp. 295-301. Cambridge University Press, Cambridge, UK.

Tutin, C.E.G. \& Fernandez, M. (1984) Nationwide census of gorilla (Gorilla g.gorilla) and chimpanzee (Pan t.troglodytes) populations in Gabon. American Journal of Primatology, 6, 313-336.

Tutin, C.E.G., Parnell, R.J., White, L.J.T. \& Fernandez, M. (1995) Nest building by lowland gorillas in the Lopé Reserve, Gabon: environmental influences and implications for censusing. International Journal of Primatology, 16, 53-76.

Usongo, L. (1998) Conservation status of primates in the proposed Lobéké Forest Reserve, south-east Cameroon. Primate Conservation, 18, 66-68.

van der Wal, M. \& Nku, E. (1999) Large Mammals of the Dja Fauna Reserve. Conservation Status and Threats. The Golden Ark Foundation / IUCN - Dja, Ministère de l'Environnement et des Forêts, Yaoundé, Cameroon.

Wildlife Conservation Society (1996) The Lobeke Forest, Southeast Cameroon. Summary of Activities Period 1983-1995. Wildlife Conservation Society, New York, USA.

Williamson, L. \& Usongo, L. (1995) Recensement des populations de primates et inventaire des grand mammiferes; Réserve de faune du Dja, Cameroon. ECOFAC (Programme for Conservation and Rational Utilization of Forest Ecosystems in Central Africa) - Composante Cameroon, Yaoundé, Cameroon.

Wrogeman, D. (1992) Wild chimpanzees in Lopé, Gabon: census method and habitat use. PhD thesis. Bremen University, Bremen, Germany.
World Society for the Protection of Animals (1995) Slaughter of the Apes: How the Tropical Timber Industry is Devouring Africa's Great Apes. World Society for the Protection of Animals, London, UK.

World Society for the Protection of Animals (2000) Bushmeat: Africa's Conservation Crisis. World Society for the Protection of Animals, London, UK.

\section{Biographical sketches}

Jef Dupain headed the bonobo project of the Royal Zoological Society of Antwerp (RZSA) in the Lomako forest, Democratic Republic of Congo, during 1994-1998, and in 2000 he set up a conservation project on the socioecology of great apes in Dja Faunal Reserve, Cameroon, involving close collaboration with local communities. He is now coordinator for the Maringa-Lopori-Wamba landscape/Congo Basin Forest Partnership for the African Wildlife Foundation.

Patrick Guislain has been involved in cognitive-ethological research on bonobos, and since 2001 he has focused on the ecological determinants of habitat use by great apes, taking part in surveys to identify suitable areas for the setting up of long-term socioecological research.

Guy Merlin Nguenang has participated in several botanical studies in and around Dja Faunal Reserve. He is responsible for characterizing vegetation types in areas surveyed by the RZSA and conducts botanical surveys for the Projet Forêt Communautaire.

Kristel De Vleeschouwer has conducted research on golden-headed lion tamarins in captivity, and is currently involved in research and conservation activities on wild golden-headed lion tamarins in Una Biological Reserve, Brazil.

Linda Van Elsacker coordinates various research projects on primates and American bison for the RZSA. 